\title{
Geomorphology-based unit hydrograph models for flood risk management: case study in Brazilian watersheds with contrasting physiographic characteristics
}

\author{
SAMUEL BESKOW ${ }^{1,2}$, GABRIELA S. NUNES ${ }^{2}$, CARLOS R. DE MELLO ${ }^{3}$, TAMARA L. CALDEIRA ${ }^{4}$, \\ LLOYD D. NORTON ${ }^{5}$, ALICE A. STEINMETZ ${ }^{2}$, MARCELLE M. VARGAS ${ }^{1}$ and LÉO F. ÁVILA ${ }^{2}$ \\ ${ }^{1}$ CDTec/Engenharia Hídrica, Universidade Federal de Pelotas/UFPel, Campus \\ Porto, Rua Gomes Carneiro, 1, 96010-610 Pelotas, RS, Brazil \\ ${ }^{2}$ CDTec/Programa de Pós-Graduação em Recursos Hídricos, Universidade Federal de Pelotas/ \\ UFPel, Campus Porto, Rua Gomes Carneiro, 1, 96010-610 Pelotas, RS, Brazil \\ ${ }^{3}$ Departamento de Engenharia, Universidade Federal de Lavras/UFLA, Grupo de Engenharia de Água \\ e Solo, Campus Universitário, s/n, Caixa Postal 3037, 37200-000 Lavras, MG, Brazil \\ ${ }^{4}$ CEng/Engenharia Civil, Universidade Federal de Pelotas/UFPel, Campus Cotada, \\ Rua Benjamim Constant, 989, 96010-020 Pelotas, RS, Brazil \\ ${ }^{5}$ Department of Agricultural and Biological Engineering, Purdue University, 225, South \\ University Street, West Lafayette, Indiana 47907-2093 United States of America
}

Manuscript received on June 7, 2017; accepted for publication on December 20, 2017

\begin{abstract}
Heavy rainfall in conjunction with an increase in population and intensification of agricultural activities have resulted in countless problems related to flooding in watersheds. Among the techniques available for direct surface runoff (DSR) modeling and flood risk management are the Unit Hydrograph (UH) and Instantaneous Unit Hydrograph (IUH). This study focuses on the evaluation of predictive capability of two conceptual IUH models (Nash and Clark), considering their original (NIUH and CIUH) and geomorphological approaches $\left(\mathrm{NIUH}_{\mathrm{GEO}}\right.$ and $\left.\mathrm{CIUH}_{\mathrm{GEO}}\right)$, and their advantages over two traditional synthetics UH models - Triangular (TUH) and Dimensionless (DUH), to estimate DSR hydrographs taking as reference two Brazilian watersheds with contrasting geomorphological and climatic characteristics. The main results and conclusions were: i) there was an impact of the differences in physiographical characteristics between watersheds, especially those parameters associated with soil; the dominant rainfall patterns in each watershed had an influence on flood modeling; and ii) CIUH was the most satisfactory model for both watersheds, followed by NIUH, and both models had substantial superiority over synthetic models traditionally employed; iii) although geomorphological approaches for IUH had performances slightly better than TUH and DUH, they should not be considered as standard tools for flood modeling in these watersheds.
\end{abstract}

Key words: Clark's IUH, Nash's IUH, direct surface runoff, hydrograph, geomorphological approach.

Correspondence to: Samuel Beskow

E-mail: samuelbeskow@gmail.com 


\section{INTRODUCTION}

Among the different observed natural hazards, Brunda and Shivakumar (2015) reported that flooding is the most frequent. According to Ma et al. (2014), several regions over the world have suffered from problems related to flooding. Its increasing trend is related to the population growth and occupation of higher risk areas, to the economic development and to the effects of climatic change on the hydrological cycle, especially on extreme events (Brunda and Shivakumar 2015, Perumal and Price 2013, Ryu et al. 2016). Floodings frequently result in a loss of human lives and of financial resources (Yadav et al. 2015); therefore, a rapid and accurate forecasting tool is fundamental for rivers prone to flooding. However, monitoring and early warning systems of floodings are not commonly used in developing countries, especially for small and medium-sized watersheds.

Stream flow data sets are fundamental to determine the hydrological response of a watershed to a heavy rainfall event whenever flood risk management or hydrological and hydraulic designs are necessary. The lack of stream flow series has culminated in the development of models, primarily intended for peak stream flow estimation and hydrographs based on a rainfall event (Beskow et al. 2015, Caldeira et al. 2015).

It has been over a century since models applied to hydrology were built to individually represent the hydrological processes (Mello et al. 2016). The first rainfall-runoff model widely used was created in 1851 by Thomas J. Mulvaney, an Irish engineer, which is today called the Rational Method. One of the first studies regarding flood hydrograph modelling began in 1921 and it can be attributed to the Australian engineer Cecil Napier Ross, who developed the concept of a time-area histogram, which seeks to represent the delay of the direct surface runoff (DSR) on each watershed zone and has been applied in various distributed hydrological models available in literature (Beven 2011).

In the case of watersheds with limited data bases, the choice of the model is considered a key step for estimation of DSR hydrographs. Unit Hydrograph (UH) theory, proposed by Le Roy K. Sherman (Sherman 1932), has been largely used. The pioneer study on synthetic UH was conducted by Snyder in 1938 based on data sets of gauged watersheds situated in the region of Appalachian (USA). Other synthetic UH models broadly accepted in literature are the Triangular and Dimensionless, developed in 1970's by Natural Resources Conservation Service (NRCS), formerly Soil Conservation Service (SCS) of United States Department of Agriculture (USDA) (McCuen and Bondelid 1983, Folmar et al. 2007). These models are simple and their relations were derived from a large number of UHs that were obtained for American watersheds with different drainage areas and locations (Nourani et al. 2009).

The UH concept was enhanced after the proposition of the Instantaneous Unit Hydrograph (IUH), which corresponds to a DSR hydrograph resulting of a unit effective rainfall $\left(\mathrm{R}_{\mathrm{e}}\right)$ with an infinitesimal duration ( $\mathrm{dt} \rightarrow 0$ ) applied uniformly over a watershed (Ahmad et al. 2009, Cleveland et al. 2006, Jeng and Coon 2003). Some conceptual models have been applied to derive IUH from $\mathrm{R}_{\mathrm{e}}$ hyetographs and DSR hydrographs (Jeng and Coon 2003), such as Clark (1945) and Nash (1957) models. Although the Nash's and Clark's IUHs, which are based on the theory of linear systems, have been widely used in some countries for hydrologic designs, their use is limited in Brazil, where traditional synthetic UH models (e.g., Triangular and Dimensionless) are mainly used instead.

UH and IUH models can be employed for gauged and ungauged watersheds (Sule and Alabi 2013). For gauged watersheds, they are derived from observed rainfall and stream flow records 
on an event basis making use of either numerical methods or conceptual modeling (e.g., Clark and Nash models). However, in the case of ungauged watersheds, geomorphological characteristics of the watershed can be used to determine necessary parameters for some synthetic models (geomorphological approaches).

Considering that conceptual IUH models depend on observed rainfall and stream flow records and, given the difficulty to have them, geomorphological approaches have been proposed to derive IUHs in watersheds. Rodriguez-Iturbe and Valdez (1979) developed a methodology that considers quantitatively the effect of the watershed geomorphology on IUH. This model can be interpreted as a probability density function of the time spent by the DSR to reach watershed's outlet since that this function depends on watershed morphology. Therefore, geomorphology is added to the IUH by means of indices associated with the drainage network. Bhagwat et al. (2011) stated that geomorphological IUH is important for programs linked to the watershed management when the absence of hydrological information is experienced. Yet, Ghumman et al. (2011) pointed out that this IUH is a useful model for prediction of hydrographs in watersheds due to the recent advances in satellite imagery and tools for data processing.

On evaluating the geomorphological approach proposed by Rodriguez-Iturbe and Valdez (1979) for estimation of Nash's IUH parameters, some scientific studies (Adib et al. 2010, Ghumman et al. 2014, Khaleghi et al. 2011) have been conducted in order to verify its applicability. Nonetheless, the results are quite variable, especially when compared to those produced by other models. Likewise, geomorphological approaches for Clark's IUH have been evaluated and the results are also contrasting among the studies (Kumar et al. 2004, Adib et al. 2010, Sahoo et al. 2006). Constant progress has been made regarding the development and application of UH and IUH models, mainly those with a geomorphological approach. Because their relations are derived from observed data sets from regions with specific characteristics, their generalization should be analyzed carefully, taking into account the region peculiarities and the quality of results.

In this context, the objective of this study was to evaluate the predictive capability of two conceptual IUH models (Nash and Clark), considering their original and geomorphological approaches, and their advantages over two traditional synthetic UH models (Triangular and Dimensionless), taking as reference the data sets of two Brazilian watersheds (Jaguara creek watershed - JCW and Cadeia river watershed - CRW) with contrasting geomorphological and climatic characteristics. $\mathrm{JCW}$ is a representative subwatershed of the Upper Grande river watershed (Southeastern Brazil) with respect to both land-use and soils classes (Oxisols predominantly) and has been a hydrology laboratory in the last 12 years. It drains towards to Camargos Hydropower Plant and has many river stretches vulnerable to flooding (SEMAD 2013). CRW has its drainage area within the municipalities of Canguçu, Morro Redondo and Pelotas, in the southern Brazil, where there have been reported many cases of natural disasters caused by flooding (CEPED 2011).

\section{MATERIALS AND METHODS}

PHYSIOGRAPHICAL CHARACTERISTICS OF THE STUDY WATERSHEDS

Two Brazilian watersheds (Figure 1) were analyzed in this study including Cadeia river watershed (CRW), situated in Rio Grande do Sul State, and Jaguara creek watershed (JCW), located in Minas Gerais State. Cadeia is one of the main tributaries of the Pelotas River, which has an approximate drainage area of $940 \mathrm{~km}^{2}$. Pelotas River is an important affluent to the São Gonçalo canal, which supplies water for human consumption and is a 


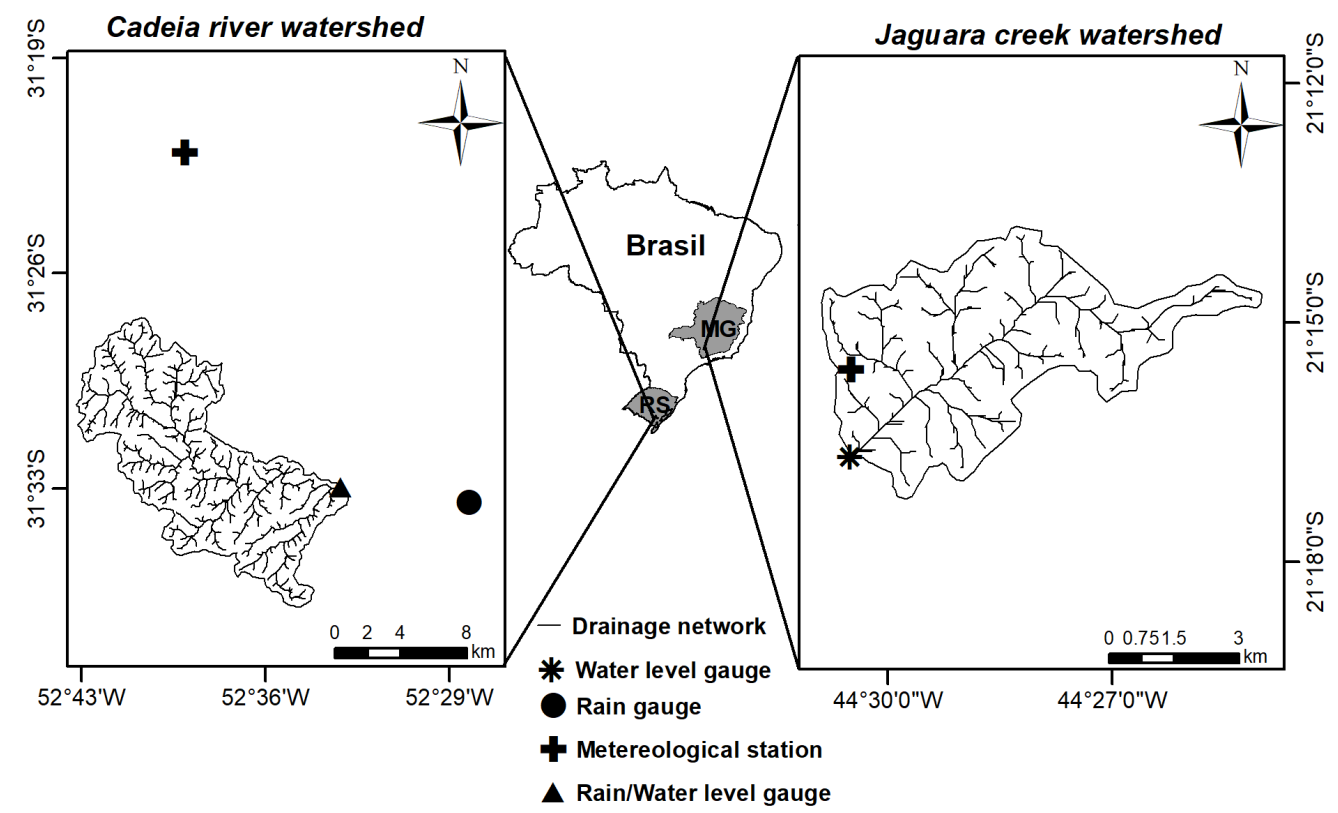

Figure 1 - Geographical location of CRW and JCW and setup of their hydrological monitoring network.

navigable watercourse that joins Patos to Mirim Lagoon. JCW has a drainage area of $29.5 \mathrm{~km}^{2}$ and is located in the Upper Grande river region, in the southern Minas Gerais (Southeastern Brazil) and drains directly into the reservoir of the Camargos hydropower plant, owned by Minas Gerais State Energy Company (CEMIG).

The information on relief for CRW was extracted from the cartographic base developed by Hasenack and Weber (2010) on a 1:50,000 scale. For JCW, the available information was a contour line map with points of known altitude obtained from Brazilian Institute of Geography and Statistics (IBGE). The geomorphological characterization of CRW and JCW was carried out in order to derive all the parameters necessary to be used as inputs for the UH and IUH models employed in this study with the aid of ArcGIS (ESRI 2014). The digital elevation model and land-use map for each watershed are illustrated in Figure 2, whereas, geomorphological characteristics and other important attributes for each watershed are summarized in Table I.

\section{HYDROLOGICAL AND METEOROLOGICAL DATA SETS}

Water stage records and the corresponding stream flow values on a thirty-minute time step were used for the outlets of both CRW and JCW. Three monitoring stations in $\mathrm{CRW}$ and one in JCW were considered for rainfall information in the same time step. Thiessen Polygons methodology was adopted to delineate the influence area of each rainfall monitoring station in the CRW and to compute aerial average rainfall in the watershed. These events allowed the elaboration of hyetographs and hydrographs, considering a 30-minute time step, which were applied for flood modeling based on $\mathrm{UH}$ and IUH theory. Given the necessity of runoff separation for UH and IUH modeling, in this study a methodology based on two inflexion points, defining the start and the end of direct surface runoff, was employed (Agirre et al. 2005, Choi et al. 2011) and the corresponding effective rainfall $\left(R_{e}\right)$ was then determined for each event $\left(R_{e}=D S R\right.$ depth). 


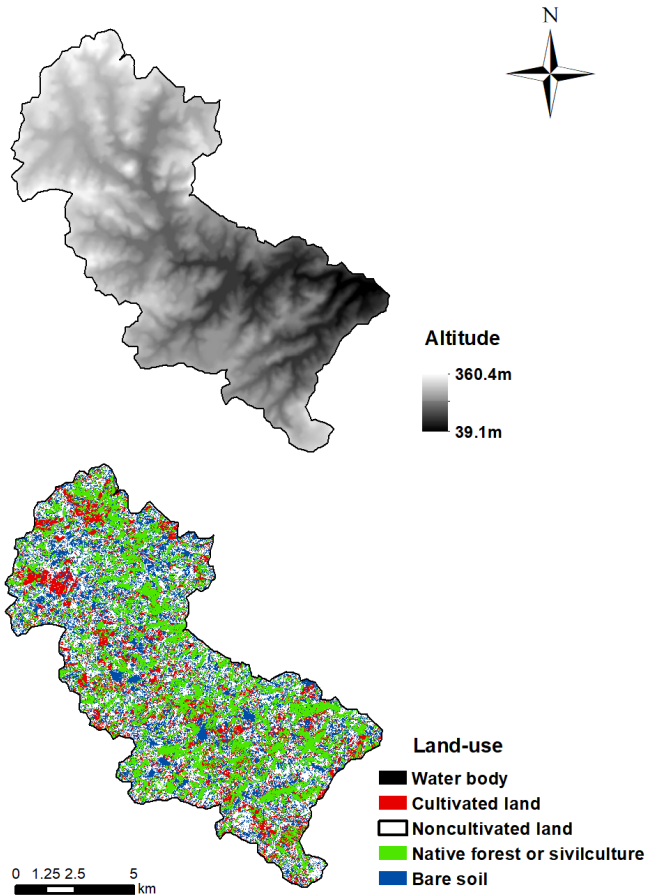

Figure 2 - a) Hydrologically Consistent Digital Elevation Model for CRW and JCW; and b) Land-use maps for CRW and JCW.

The $\mathrm{R}_{\mathrm{e}}$ hyetographs were determined using the Curve Number method (SCS 1971) following the procedures recommended by Chow et al. (1988) and applied in many flood modeling sudies (Beskow et al. 2009, Choi et al. 2011, López et al. 2012). Initial abstraction ( $\left.I_{a}\right)$ was considered as the cumulative rainfall until the start time of the DSR observed on the hydrograph and the corresponding Curve Number $(\mathrm{CN})$ was adjusted for each event.

\section{HYDROLOGICAL MODELING OF FLOOD HYDROGRAPHS}

\section{Unit hydrograph (UH) models}

In this study, two synthetic Unit Hydrograph models were evaluated: Triangular Unit Hydrograph (TUH) and Dimensionless Unit Hydrograph (DUH). These models were developed by SCS (1971) and are based on the analysis of a number of UHs derived from US watersheds with different drainage areas. The rising time $\left(\mathrm{t}_{\mathrm{a}}\right)$ for TUH and DUH is considered as the sum of half time of the unit precipitation $\left(\mathrm{P}_{\mathrm{u}}\right)$ duration and basin lag time $\left(t_{\text {lag }}\right)$. The latter parameter accounts for the time from half of the unit precipitation $\left(\mathrm{P}_{\mathrm{u}}\right)$ to the peak stream flow observed on the hydrograph. In this study, $\mathrm{P}_{\mathrm{u}}$ was defined as $1 \mathrm{~mm}$ occurring uniformly on the watershed during a time D of 30 minutes, while $t_{\text {lag }}$ was estimated employing the following equation (SCS, 1971):

$$
\mathrm{t}_{\mathrm{lag}}=\frac{2.6 \cdot \mathrm{L}^{0.80} \cdot\left(\frac{\mathrm{S}}{25.4}+1\right)^{0.70}}{1900 \cdot \mathrm{X}^{0.50}}
$$

where $\mathrm{t}_{\text {lag }}$ is the basin lag time (h), $L$ corresponds to the length of the main river (m), $S$ is the soil potential maximum water storage $(\mathrm{mm})$, which is based on the Curve Number value, and $\mathrm{X}$ is the mean watershed slope (\%). The $\mathrm{CN}$ value adjusted for each event was used in Equation 1 to calculate S.

The peak stream flow $\left(\mathrm{q}_{\mathrm{p}}\right)$ for TUH and DUH was obtained by the relationship: 
TABLE I

Land-use and soil classes and geomorphological and meteorological/climatic characterization of Cadeia river watershed (CRW) and Jaguara creek watershed (JCW).

\begin{tabular}{|c|c|c|c|c|c|c|c|}
\hline \multicolumn{4}{|c|}{ Cadeia river watershed $(\mathrm{CRW})$} & \multicolumn{4}{|c|}{ Jaguara creek watershed (JCW) } \\
\hline Land-use & $\begin{array}{c}\% \text { of the } \\
\text { area }\end{array}$ & Soil class ${ }^{1}$ & $\begin{array}{l}\% \text { of } \\
\text { the } \\
\text { area }\end{array}$ & Land-use $^{2}$ & $\begin{array}{l}\% \text { of the } \\
\text { area }\end{array}$ & Soil class ${ }^{2}$ & $\begin{array}{l}\% \text { of } \\
\text { the } \\
\text { area }\end{array}$ \\
\hline Water body & 0.1 & $\begin{array}{l}\text { Red-Yellow } \\
\text { Argisol } \\
\text { (Ultisol) }\end{array}$ & 41.6 & Eucalyptus & 7.7 & Latosol (Oxisol) & 59.8 \\
\hline $\begin{array}{l}\text { Cultivated land (Annual/ } \\
\text { permanent cropping or } \\
\text { pasture) }\end{array}$ & 13.9 & $\begin{array}{l}\text { Grayish } \\
\text { Brown Argisol } \\
\text { (Ultisol) }\end{array}$ & 58.4 & Coffee crop & 4.1 & $\begin{array}{l}\text { Haplic Cambisol } \\
\text { (Inceptisol) }\end{array}$ & 23.4 \\
\hline Native forest or silviculture & 31.0 & & & Bare soil & 9.6 & $\begin{array}{l}\text { Fluvic Neosol } \\
\quad \text { (Fluvent) }\end{array}$ & 16.8 \\
\hline $\begin{array}{l}\text { Noncultivated land } \\
\text { (grassland or subble) }\end{array}$ & 30.0 & & & Maize & 22.9 & & \\
\hline \multirow[t]{2}{*}{ Bare soil } & 25.0 & & & Native vegetation & 13.1 & & \\
\hline & & & & Pasture & 42.6 & & \\
\hline \multicolumn{4}{|c|}{ Geomorphological characteristics } & \multicolumn{4}{|c|}{ Geomorphological characteristics } \\
\hline Drainage area $\left(\mathrm{km}^{2}\right)$ & 121.2 & & & $\begin{array}{l}\text { Drainage area } \\
\quad\left(\mathrm{km}^{2}\right)\end{array}$ & 29.5 & & \\
\hline Length ratio $\left(R_{L}\right)$ & 2.9 & & & Length ratio $\left(R_{L}\right)$ & 1.9 & & \\
\hline Bifurcation ratio $\left(\mathrm{R}_{\mathrm{B}}\right)$ & 4.1 & & & $\begin{array}{l}\text { Bifurcation ratio } \\
\qquad\left(R_{B}\right)\end{array}$ & 3.6 & & \\
\hline Ratio between areas $\left(\mathrm{R}_{\mathrm{A}}\right)$ & 4.8 & & & $\begin{array}{l}\text { Ratio between } \\
\text { areas }\left(\mathrm{R}_{\mathrm{A}}\right)\end{array}$ & 4.5 & & \\
\hline \multicolumn{4}{|c|}{ Meteorological/Climatic characteristics } & \multicolumn{4}{|c|}{ Meteorological/Climatic characteristics } \\
\hline $\begin{array}{l}\text { Köppen climate } \\
\text { classification }\end{array}$ & $\mathrm{Cfa}^{3}$ & & & $\begin{array}{l}\text { Köppen climate } \\
\text { classification }\end{array}$ & $\mathrm{Cwa}^{4}$ & & \\
\hline Mean annual rainfall (mm) & 1,367 & & & $\begin{array}{l}\text { Mean annual } \\
\text { rainfall (mm) }\end{array}$ & $1,400^{4}$ & & \\
\hline
\end{tabular}

${ }^{1}$ Brasil (1973) classified according to Embrapa (2013) and IUSS Working Group WRB (2015); ${ }^{2}$ Beskow et al. (2013), ${ }^{3}$ Kuinchtner and Buriol (2001), ${ }^{4}$ Mello et al. (2008).

$$
\mathrm{q}_{\mathrm{p}}=\frac{0.208 \cdot \mathrm{P}_{\mathrm{u}} \cdot \mathrm{A}}{\mathrm{t}_{\mathrm{a}}}
$$

where $\mathrm{q}_{\mathrm{p}}$ is in $\mathrm{m}^{3} \cdot \mathrm{s}^{-1}, \mathrm{P}_{\mathrm{u}}$ corresponds to the unit rainfall $(\mathrm{mm}), \mathrm{A}$ is watershed area $\left(\mathrm{km}^{2}\right)$, and $\mathrm{t}_{\mathrm{a}}$ is the rising time $(\mathrm{h})$.

Once $t_{a}, q_{p}$ and base time $\left(t_{b}\right)$ have been determined, the TUH's ordinates are defined at each time of interest. The DUH's ordinates are calculated from the ratio between stream flow and peak stream flow $\left(q / q_{p}\right)$ for a number of ratios of time over rising time $\left(\mathrm{t} / \mathrm{t}_{\mathrm{a}}\right)$ in accordance with the equation:

$$
\frac{\mathrm{q}}{\mathrm{q}_{\mathrm{p}}}=\left[\frac{\mathrm{t}}{\mathrm{t}_{\mathrm{a}}} \cdot \exp \left(1-\frac{\mathrm{t}}{\mathrm{t}_{\mathrm{a}}}\right)\right]^{\mathrm{X}}
$$

where $X$ corresponds to a Gamma function of the peak factor (FP), which is commonly considered as 484 (Folmar et al. 2007).

The estimated DSR hydrograph (Q), using TUH and DUH, was derived from the convolution 
equation (Equation 4) in its discrete form for each UH model (TUH and DUH), event and watershed, which was compared to the respective observed hydrograph. For Equation 4 application, it is necessary to define the $\mathrm{R}_{\mathrm{e}}$ hyetograph in relation to the $\mathrm{P}_{\mathrm{u}}$ considered $\left(\mathrm{P}=\mathrm{R}_{\mathrm{e}} / \mathrm{P}_{\mathrm{u}}\right)$, representing a rainfall event occurring uniformly on the watershed of interest and the watershed's UH ( $q$ ordinates).

$$
Q_{M}=\sum_{1}^{N}\left(P_{N} \cdot q_{M-N+1}\right)
$$

where $M$ is the ordinate of the estimated DSR hydrograph and $\mathrm{N}$ corresponds to the number of $\mathrm{R}_{\mathrm{e}}$ intervals. In both watersheds, a 30-min interval was used for the stream flows.

\section{Instantaneous Unit Hydrograph (IUH) models}

In this study, Nash's IUH (NIUH), Clark's IUH (CIUH), Nash's Geomorphological IUH $\left(\mathrm{NIUH}_{\mathrm{GEO}}\right)$ and Clark's Geomorphological IUH $\left(\mathrm{CIUH}_{\mathrm{GEO}}\right)$ were evaluated for each event and watershed. In all the IUH models assessed, the IUH was converted into an $\mathrm{UH}$, considering $\Delta \mathrm{t}=30 \mathrm{~min}$, similarly to the procedure employed by López et al. (2012). Afterwards, the estimated DSR hydrograph (Q) was also derived using the convolution equation (Equation 4) in discrete form for each IUH model.

\section{a) Nash's IUH (NIUH)}

This model (Nash, 1957) considers that a uniform rainfall occurs throughout the watershed and the surface runoff generated is routed to the respective outlet. The reservoirs account for both attenuations of peak stream flow and translation. The behavior of the reservoir in terms of surface runoff drainage is represented by a parameter $k$, which reflects the watershed response to the occurrence of one or more effective rainfall events.

The NIUH is described by:

$$
u(t)=\frac{1}{k \cdot \Gamma(n)} \cdot\left(\frac{t}{k}\right)^{n-1} \cdot e^{\frac{-t}{k}}
$$

where $u(t)$ denotes the NIUH's ordinates, $t$ is the time interval, $n$ and $k$ correspond to the NIUH's parameters and $\Gamma$ the Gamma function. The parameter $k$ (scale) is equal for all the linear reservoirs and represents a storage constant, having a time unit; the parameter $n$ (shape) is the number of linear reservoirs attenuating the IUH's peak stream flow.

The estimation of $n$ and $k$ for each event was carried out in accordance with the procedures described by Nash (1957), which are based on observed records derived from hyetographs and hydrographs.

\section{b) Clark's IUH (CIUH)}

The CIUH considers two important processes related to the transformation of effective rainfall into surface runoff (Clark 1945) - attenuation and translation. The application of the CIUH requires the estimation of two parameters (Ahmad et al. 2009, Che et al. 2014): time of concentration $\left(t_{c}\right)$ and storage coefficient $(\mathrm{R})$. Its mathematical formulation is given by:

$$
\mathrm{u}_{\mathrm{i}+1}=2 \cdot \mathrm{C}_{0} \cdot \mathrm{R}_{\mathrm{E}(\mathrm{i})}+\mathrm{C}_{1} \cdot \mathrm{u}_{\mathrm{i}}
$$

where $\mathrm{u}$ is the CIUH's ordinate, $\mathrm{i}$ refers to time, $\mathrm{R}_{\mathrm{E}}$ corresponds to the effective rainfall uniformly distributed which depends on both the Time-Area Histogram (TAH) and a constant for conversion of units, and $\mathrm{C}_{0}$ and $\mathrm{C}_{1}$ are weighting coefficients.

In this study, TAH was obtained with the aid of a tool named as Watershed Isochrones, a computer tool within the ArcGIS environment, developed by the team of the Hydrology and Hydrological Modeling Laboratory, at the Federal University of Pelotas (Brazil). As TAHs depend on the determination of $t_{c}$, which in turn was adjusted for each rainfall event and watershed, they were elaborated from 30 minutes to 25 hours and between 30 minutes and 12 hours were made for CRW and JCW, respectively, in order to cover all the events in each watershed. The parameter R, in turn, was 
estimated seeking to minimize a given objective function through comparison between observed and estimated stream flows. All the procedures used in this study are in accordance with those applied by Che et al. (2014).

c) Nash's Geomorphological IUH ( $\mathrm{NIUH}_{\text {GEO }}$ )

In this study, the $\mathrm{NIUH}_{\mathrm{GEO}}$ was considered through the formula for $n$ and $k$ proposed by Bhagwat et al. (2011), relating the IUH's scale (k) and shape (n) parameters to the Horton's ratios, based on the results of Rodriguez-Iturbe and Valdez (1979), as follows:

$q_{p} \cdot t_{a}=\frac{n-1}{\Gamma(n)} e^{-(n-1)} \cdot n-1^{n-1}=0.5764 \cdot\left(\frac{R_{B}}{R_{A}}\right)^{0.55} \cdot R_{L}^{0.05}$

where $R_{B}$ and $R_{L}$ correspond to the Horton's laws, represented by bifurcation ratio $\left(\mathrm{R}_{\mathrm{B}}\right)$ and length ratio $\left(R_{L}\right)$, and $R_{A}$ is defined as the ratio between areas of the watershed.

All the terms of the right side of the Eq. 7 can be calculated because they depend on the geomorphological characteristics of the watershed (Table I). The parameter $n$ was iteratively determined in accordance with Eq. 7, whereas, $k$ was computed through the aforementioned dimensionless indices following recommendations of Bhagwat et al. (2011):

$\mathrm{k}=\frac{0.44 \cdot \mathrm{L}}{\mathrm{V}} \cdot\left(\frac{\mathrm{R}_{\mathrm{B}}}{\mathrm{R}_{\mathrm{A}}}\right)^{0.55} \cdot \mathrm{R}_{\mathrm{L}}^{-0.38} \cdot(\mathrm{n}-1)^{-1}$

where $\mathrm{V}$ is the dynamic velocity $\left(\mathrm{m} . \mathrm{s}^{-1}\right)$. Its determination was in accordance with the criterion indicated by Zelazinski (1986) and applied in other scientific studies (e.g., Ghumman et al. 2011, 2014, Kumar et al. 2002).

d) Clark's Geomorphological IUH $\left(\mathrm{CIUH}_{\mathrm{GEO}}\right)$

The CIUH is based on two parameters $\left(t_{c}\right.$ and $R$ ) and on the determination of the watershed's TAH. For the application of the $\mathrm{CIUH}_{\mathrm{GEO}}, t_{c}$ was estimated considering the empirical equations of Dodge and Ven Te Chow for CRW and JCW, respectively, considering their limitations regarding watershed's size. The storage coefficient (R) was estimated following the recommendation of Mohave County (2009):

$\mathrm{R}=\frac{0.435 \cdot \mathrm{t}_{\mathrm{c}}^{1.11} \cdot \mathrm{L}^{0.8}}{\mathrm{~A}^{0.57}}$

where $t_{c}$ is the time of concentration (hours), $L$ corresponds to the maximum flow length $(\mathrm{km})$, and $A$ refers to the watershed area $\left(\mathrm{km}^{2}\right)$.

The TAH for each watershed, corresponding to the $t_{c}$ previously calculated, was obtained with the aid of the "Watershed Isochrones" tool. However, for the $\mathrm{CIUH}_{\mathrm{GEO}}, R$ and $t_{c}$ were considered invariable in relation to the event, thereby, corresponding to a unique value for each watershed.

\section{PERFORMANCE OF THE MODELS}

Performance analysis was carried out by means of two statistical measures: Nash and Sutcliffe efficiency coefficient $\left(\mathrm{C}_{\mathrm{NS}}\right)$ (Nash and Sutcliffe 1970), and relative error in the estimation of peak stream flow $\left(\mathrm{RE}_{\mathrm{Qp}}\right)$. Moriasi et al. (2007) suggest the following $\mathrm{C}_{\mathrm{NS}}$ classification: $\mathrm{C}_{\mathrm{NS}}>0.65$, very good fit; $0.54<\mathrm{C}_{\mathrm{NS}}<0.65$, good fit; $0.50<\mathrm{C}_{\mathrm{NS}}$ $<0.54$, satisfactory fit. In order to classify the estimation of hydrographs with respect to $\mathrm{RE}_{\mathrm{QP}}$, the classification proposed by Van Liew et al. (2007) was used: $\left|\mathrm{RE}_{\mathrm{QP}}\right|<10 \%$, very good fit; $10 \%<\left|\mathrm{RE}_{\mathrm{QP}}\right|$ $<15 \%$, good fit; $15 \%<\left|\mathrm{RE}_{\mathrm{QP}}\right|<25 \%$, satisfactory fit; and $\left|\mathrm{RE}_{\mathrm{QP}}\right|>25 \%$, inadequate fit.

\section{RESULTS AND DISCUSSION}

In order to have different scenarios of hydrological response, 12 rainfall-runoff events were evaluated in the CRW (Table II) and 20 events in the JCW (Table III). Some rainfall-runoff events were plotted in Figure 3 and Figure 4 for CRW and $\mathrm{JCW}$, respectively, to emphasize the differences in hydrological behavior between these watersheds. 
It can be observed in Tables II and III, that there was a substantial variability in $\mathrm{R}_{\mathrm{e}}$ values (CRW, 0.4 to $46.6 \mathrm{~mm}$; JCW, 0.3 to $21.6 \mathrm{~mm}$ ). This wide range of values is desired for UH modeling since it makes the analysis of models' performance broader. It was found that CRW (Figure 3) had rainfall events with duration considerably longer than JCW (Figure 4), which can be attributed to the predominant rainfall climatology of each watershed with respect to the events analyzed (CRW - frontal rainfall and JCW convective rainfall).

On analyzing $\mathrm{CN}$ values (Tables II and III), adjusted for the rainfall-runoff events, one can observe that they were clearly variable among the events, ranging from 11.4 to 87.8 and from 24.8 to 98.7 for CRW and JCW, respectively. Findings similar to these were reported by Agirre et al. (2005) and López et al. (2012). Overall, it was observed a difference between the watersheds with respect to the delay for the beginning of surface runoff, which is related the longer rainfall events observed in CRW, thus culminating in lower maximum rainfall intensities (Figure 3). Such characteristics result in a greater potential for infiltration at the beginning of the rainfall event due to both the lower rainfall intensities and need of a longer time interval to satisfy initial abstractions $\left(\mathrm{I}_{\mathrm{a}}\right)$.

The assessment of the contrasting rainfall types (Figure 3 and Figure 4) should be analyzed in conjunction with the soil types in both watersheds. According to classification of Embrapa (2013), the classes correspond to Red-Yellow Argisol and Grayish Brown Argisol. The argisols are normally deep to very deep soils, varying from well drained to imperfectly drained, and have a sequence of A-Bt-C or A-E-Bt-C horizons in that the B horizon is and increased clay texture in the Bt (Streck et al. 2008). The Grayish Brown Argisols differ from Red-Yellow Argisols basically due to their location in landscape, occurring in lowlands, thereby favoring more accumulation of water and organic matter. However, the predominant soil in JCW is Oxisols, which are very deep, with a high porosity and high clay content but occurring as strong aggregates (Beskow et al. 2013). These differing soil characteristics help elucidate why JCW tends

TABLE II

Characterization of the rainfall-runoff events used for flood modeling in the CRW, describing the rainfall $\left(R_{\text {TотАL }}\right)$, duration of event (D), mean rainfall intensity $\left(i_{m}\right)$, maximum mean 30-minute intensity ( $i_{m 30}$ ), antecedent 5-day rainfall

$\left(R_{5}\right)$, effective rainfall $\left(R_{e}\right)$, peak direct surface runoff discharge $\left(Q_{P E A K}\right)$, observed lag time $\left(t_{\text {lag }}{ }^{*}\right)$ and adjusted curve number $\left(\mathrm{CN}^{*}\right)$.

\begin{tabular}{|c|c|c|c|c|c|c|c|c|c|}
\hline Event & $\begin{array}{c}\mathbf{R}_{\text {TOTAL }} \\
(\mathbf{m m})\end{array}$ & $\begin{array}{c}\text { D } \\
\text { (h) }\end{array}$ & $\underset{\left(\mathrm{mm} \cdot \mathrm{h}^{-1}\right)}{\mathbf{i}_{\mathrm{m}}}$ & $\begin{array}{c}i_{\mathrm{m} 30}, \\
\left(\mathrm{~mm} \cdot \mathrm{h}^{-1}\right)\end{array}$ & $\begin{array}{c}R_{5} \\
(\mathbf{m m})\end{array}$ & $\begin{array}{c}R_{\mathrm{e}} \\
(\mathbf{m m})\end{array}$ & $\begin{array}{c}Q_{\text {PEAK }} \\
\left(\mathbf{m}^{3} \cdot \mathrm{s}^{-1}\right)\end{array}$ & $\begin{array}{l}\mathrm{t}_{\mathrm{lag}}{ }^{*} \\
\text { (h) }\end{array}$ & $\mathrm{CN}^{*}$ \\
\hline 1 & 43.8 & 27.0 & 4.2 & 26.0 & 124.3 & 6.0 & 27.1 & 1.9 & 66.2 \\
\hline 2 & 67.6 & 36.0 & 4.2 & 15.2 & 12.3 & 4.8 & 16.5 & 3.5 & 51.9 \\
\hline 3 & 41.2 & 30.0 & 2.1 & 11.2 & 1.2 & 1.7 & 4.8 & 5.9 & 35.4 \\
\hline 4 & 59.6 & 38.5 & 2.6 & 8.8 & 16.7 & 2.0 & 5.5 & 6.0 & 21.7 \\
\hline 5 & 110.8 & 81.5 & 2.8 & 10.4 & 5.4 & 21.3 & 43.6 & 5.5 & 42.8 \\
\hline 6 & 40.0 & 26.5 & 2.8 & 12.0 & 2.6 & 1.8 & 5.7 & 7.3 & 36.6 \\
\hline 7 & 92.4 & 42.0 & 5.0 & 25.6 & 77.4 & 46.6 & 162.5 & 3.1 & 81.3 \\
\hline 8 & 72.2 & 25.0 & 16.0 & 54.0 & 0.4 & 9.6 & 48.6 & 4.4 & 37.2 \\
\hline 9 & 27.2 & 11.5 & 18.1 & 31.2 & 0.1 & 0.4 & 2.6 & 3.9 & 11.4 \\
\hline 10 & 36.0 & 13.5 & 3.7 & 34.8 & 20.5 & 0.9 & 5.2 & 4.6 & 41.5 \\
\hline 11 & 23.2 & 17.0 & 5.4 & 10.4 & 10.1 & 1.1 & 4.7 & 5.0 & 87.8 \\
\hline 12 & 66.6 & 26.5 & 2.6 & 26.4 & 3.6 & 11.0 & 46.8 & 4.3 & 69.7 \\
\hline
\end{tabular}



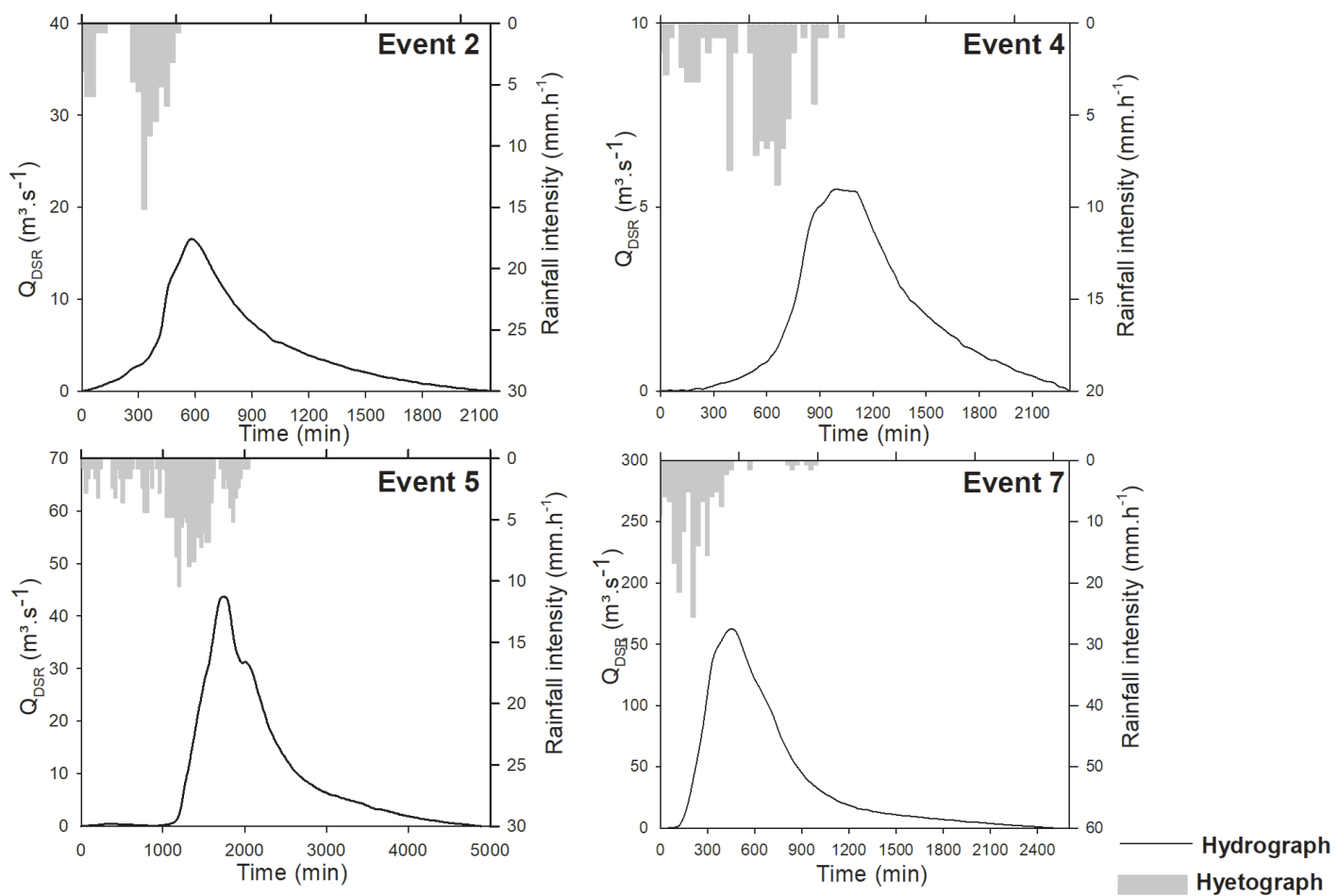

Figure 3 - Illustration of some rainfall-runoff events analyzed in CRW.
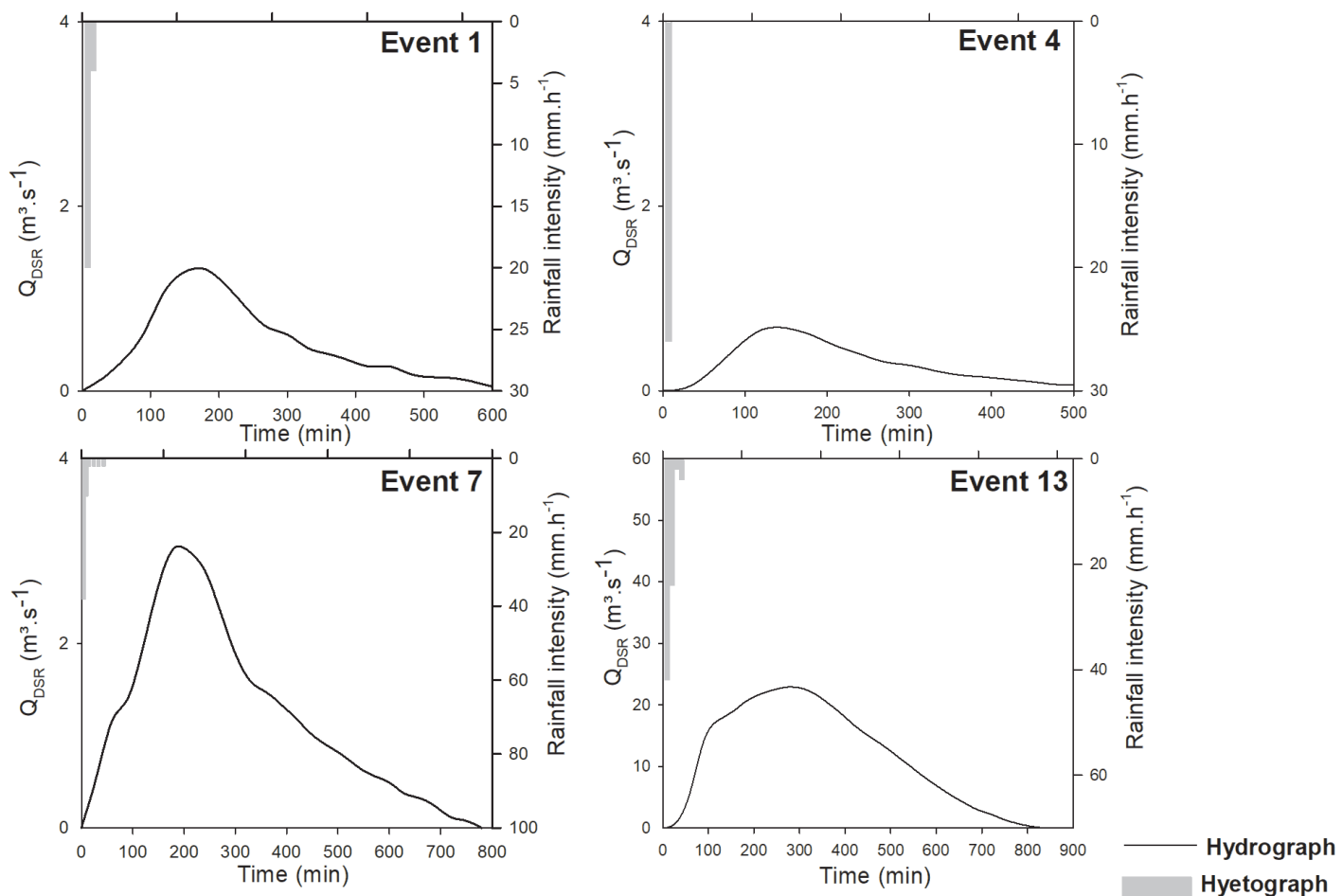

Figure 4 - Illustration of some rainfall-runoff events analyzed in JCW. 
TABLE III

Characterization of the rainfall-runoff events used for flood modeling in the JCW, describing the rainfall $\left(R_{\text {TотАL }}\right)$, duration of event $(D)$, mean rainfall intensity $\left(i_{m}\right)$, maximum mean 30-minute intensity $\left(i_{m 30}\right)$, antecedent 5-day rainfall $\left(R_{5}\right)$, effective rainfall $\left(R_{e}\right)$, peak direct surface runoff discharge $\left(Q_{\mathrm{PEAK}}\right)$, observed lag time $\left(t_{\mathrm{lag}}{ }^{*}\right)$ and adjusted curve number $\left(\mathrm{CN}^{*}\right)$.

\begin{tabular}{|c|c|c|c|c|c|c|c|c|c|}
\hline Event & $\begin{array}{c}R_{\text {TOTAL }} \\
(\mathbf{m m})\end{array}$ & $\begin{array}{l}\text { D } \\
\text { (h) }\end{array}$ & $\underset{\left(m m \cdot h^{-1}\right)}{i_{m}}$ & $\begin{array}{c}\mathbf{i}_{\mathrm{m} 30}, \\
\left(\mathrm{~mm} \cdot \mathrm{h}^{-1}\right)\end{array}$ & $\begin{array}{c}R_{5} \\
(\mathbf{m m})\end{array}$ & $\begin{array}{c}R_{\mathrm{e}} \\
(\mathbf{m m})\end{array}$ & $\begin{array}{c}Q_{\text {PEAK }} \\
\left(\mathbf{m}^{3} \cdot \mathbf{s}^{-1}\right)\end{array}$ & $\begin{array}{l}\mathbf{t}_{\text {lag }} * \\
\text { (h) }\end{array}$ & $\mathrm{CN}^{*}$ \\
\hline 1 & 14.0 & 10.5 & 12.0 & 20.0 & 38.0 & 0.7 & 1.3 & 2.6 & 54.3 \\
\hline 2 & 44.0 & 15.0 & 8.9 & 32.0 & 44.0 & 5.3 & 6.2 & 2.2 & 49.3 \\
\hline 3 & 8.0 & 13.5 & 3.3 & 6.0 & 35.0 & 3.0 & 4.7 & 4.3 & 98.7 \\
\hline 4 & 13.0 & 9.0 & 26.0 & 26.0 & 37.0 & 0.3 & 0.7 & 2.3 & 32.1 \\
\hline 5 & 30.0 & 20.5 & 3.4 & 6.0 & 6.0 & 2.9 & 3.0 & 3.3 & 53.2 \\
\hline 6 & 59.0 & 18.5 & 4.2 & 24.0 & 15.0 & 5.0 & 6.5 & 3.9 & 42.8 \\
\hline 7 & 29.0 & 13.0 & 6.2 & 38.0 & 39.0 & 2.0 & 3.0 & 2.0 & 40.3 \\
\hline 8 & 28.0 & 12.5 & 10.0 & 20.0 & 74.0 & 1.6 & 2.7 & 1.3 & 41.2 \\
\hline 9 & 72.0 & 16.0 & 4.7 & 64.0 & 83.0 & 18.4 & 18.0 & 4.3 & 68.9 \\
\hline 10 & 99.0 & 15.0 & 19.8 & 72.0 & 111.0 & 21.6 & 23.3 & 2.8 & 52.6 \\
\hline 11 & 12.0 & 13.5 & 1.8 & 16.0 & 210.0 & 3.7 & 5.0 & 3.3 & 96.5 \\
\hline 12 & 41.0 & 15.5 & 13.7 & 44.0 & 14.0 & 8.5 & 12.1 & 3.3 & 72.7 \\
\hline 13 & 49.0 & 14.0 & 16.3 & 42.0 & 77.0 & 20.0 & 22.9 & 3.5 & 79.1 \\
\hline 14 & 61.0 & 18.0 & 8.1 & 70.0 & 0.0 & 4.5 & 5.5 & 2.7 & 25.1 \\
\hline 15 & 86.0 & 28.5 & 14.0 & 44.0 & 39.0 & 11.7 & 11.8 & 4.2 & 46.0 \\
\hline 16 & 62.0 & 16.0 & 3.8 & 34.0 & 173.0 & 6.1 & 7.0 & 0.6 & 49.5 \\
\hline 17 & 39.0 & 16.0 & 3.9 & 36.0 & 48.0 & 4.9 & 6.3 & 2.7 & 64.1 \\
\hline 18 & 65.0 & 16.0 & 9.2 & 38.0 & 63.0 & 10.0 & 13.1 & 2.3 & 50.5 \\
\hline 19 & 53.0 & 16.0 & 9.6 & 58.0 & 6.0 & 3.3 & 4.5 & 2.8 & 24.8 \\
\hline 20 & 26.0 & 10.5 & 4.7 & 48.0 & 58.0 & 1.7 & 3.2 & 2.8 & 40.0 \\
\hline
\end{tabular}

to experience more infiltration when compared to the CRW.

The models' performance can be evaluated in accordance with two statistical measures $\left(\mathrm{C}_{\mathrm{NS}}\right.$ and $\mathrm{RE}_{\mathrm{Qp}}$ ) for each event considered as summarized in Tables IV and V.

The $\mathrm{C}_{\mathrm{NS}}$ results from Tables IV and $\mathrm{V}$ indicate that the hydrographs on average were closer to those observed for both CRW and JCW when deriving from $\mathrm{CIUH}$, followed by NIUH. On the other hand, the use of the DUH and NIUH $_{\text {GEO }}$ resulted in the lowest performance for CRW and $\mathrm{JCW}$, respectively. With respect to $\mathrm{RE}_{\mathrm{Qp}}$ the same behavior was verified.

Yet analyzing $\mathrm{C}_{\mathrm{NS}}$ values, it was found that all the hydrographs estimated by both CIUH and NIUH to CRW fell into the "Very good fit" category according to the classification proposed by Moriasi et al. (2007). In the case of the JCW, the CIUH and NIUH resulted in hydrographs classified as "Very good fit" for all the events, except for event 16 (NIUH). However, CIUH resulted in a performance markedly greater than NIUH for JCW ( see $\mathrm{C}_{\mathrm{NS}}$ values in Tables IV and $\mathrm{V}$ ).

Taking the $\mathrm{ER}_{\mathrm{Qp}}$ statistic as reference, $\mathrm{CIUH}$ generated peak stream flows more accurate for a greater number of events in CRW (Table IV) when compared to the other models. The DUH model produced the worst peak stream flow estimation for CRW, while TUH, $\mathrm{CIUH}_{\mathrm{GEO}}$ and $\mathrm{NIUH}_{\mathrm{GEO}}$ also had lesser performances with hydrographs estimated for 
various events framed as "Inadequate" (Van Liew et al. 2007). For JCW (Table V), peak stream flows were better estimated by CIUH and NIUH, while TUH, DUH, NIUH ${ }_{\text {GEO }}$ and $\mathrm{CIUH}_{\mathrm{GEO}}$ produced estimations classified as "Inadequate" for most of the events, thereby indicating that hydrologists should not apply such models, especially for peak stream flow estimation.

One can observe in Table IV that TUH and DUH models had unsatisfactory performance (see $\mathrm{C}_{\mathrm{NS}}$ values) for CRW, as only three and four events, respectively, out of 12 events presented estimated hydrographs framed as "Good fit" or "Very good fit". Relative to JCW (Table V), the behavior was similar as TUH and DUH models resulted in estimations classified as "Good fit" or "Very good fit" for six and five events, respectively, out of 20 events. The difficulties found in this study with respect to the accuracy of the hydrographs estimated by TUH and DUH go along with results obtained in other studies, such as in Khaleghi et al. (2011) and Zakizadeh and Malekinezhad (2015).

The low performance observed in the present study regarding TUH and DUH models (Tables IV and V) can be partially attributed to the difference between observed and estimated $t_{\text {lag }}$ values. Considering the monitored events (hyetograph versus hydrograph), the observed $t_{\text {lag }}$ values for CRW (Table I) ranged from 1.9 to 7.3 hours (average value of 4.6 hours), while for JCW (Table II), values between 0.6 and 4.3 hours (average value of 2.9 hours) were found. Otherwise, estimated $t_{\text {lag }}$ values were noticeably variable when analyzing a rainfall-runoff event at a time (CRW - $2.4 \mathrm{~h}$ to 27.6 $\mathrm{h}$; and JCW $-0.74 \mathrm{~h}$ to $7.5 \mathrm{~h}$ ).

The parameter $t_{\text {lag }}$ varies directly in function of the river length. Also, $\mathrm{t}_{\mathrm{lag}}$ is directly proportional to $S$ and, consequently, inversely proportional to $C N$, thus reflecting the watershed's soil, land use and antecedent soil moisture characteristics. In general, $\mathrm{t}_{\text {lag }}$ was overestimated, especially for CRW; this might have led to underestimates of unit peak stream flows $\left(\mathrm{q}_{\mathrm{p}}\right)$. This discrepancy in $t_{\text {lag }}$ values has been also found in other studies as that carried out by Khaleghi et al. (2011), who evaluated the TUH and DUH to the Kasilian watershed (Iran) based on 21 events and found values from 2.6 to 7.4 hours. It should be emphasized that even using $\mathrm{CN}$ values adjusted for each event, $\mathrm{t}_{\text {lag }}$ values were overestimated, thus indicating that the Equation 1 proposed by SCS (1971) should be carefully applied.

The NIUH model had satisfactory performance for both watersheds (Tables IV and V), with $\mathrm{C}_{\mathrm{NS}}$ values ranging from 0.65 to 0.98 and between 0.20 and 0.95 for CRW and JCW, respectively. On evaluating NIUH, CIUH and CIUH $_{\text {GEO }}$ for seven events in a watershed located in the central region of India, Kumar et al. (2002) noted that NIUH produced the best results for four events. Other studies also presented good results when applying NIUH, as Agirre et al. (2005), Saravanan and Manjula (2015), Zakizadeh and Malekinezhad (2015). Even though the NIUH and CIUH are based on observed rainfall-runoff records, Adib et al. (2010) reported that these models may not be capable of estimating DSR hydrographs for specific rainfall events. The results of this study do not corroborate the statement of Adib et al. (2010) because all the events were classified as "Very good fit" $\left(\mathrm{C}_{\mathrm{NS}}\right.$ values) acording to Moriasi et al. (2010), except when analyzing the potential of NIUH to estimate peak discharges for some events in JCW in which $\mathrm{RE}_{\mathrm{Op}}$ values were greater than $25 \%$ (Table V) (Van Liew et al. 2007).

On analyzing the applicability of NIUH for the rainfall-runoff events, it was possible to observe that CRW had an average $n$ of 2.6, whereas, for $\mathrm{JCW}$, it was 2.9. Relative to $k$ parameter, it was found an average value of $3.3 \mathrm{~h}$ for CRW and 1.7 $\mathrm{h}$ for JCW. The amplitude and variability of $n$ and $k$ values observed in the events evaluated in this study corroborate the findings of several other studies, such as Kumar et al. (2002), Adib et al. 
TABLE IV

Nash-Sutcliffe coefficient $\left(C_{\mathrm{NS}}\right)$ and peak stream flow relative error $\left(\mathrm{RE}_{\mathrm{Qp}}\right)$ for each rainfall-runoff event monitored at CRW, considering the UH and IUH models analyzed in this study.

\begin{tabular}{ccccccccccccc}
\hline \multicolumn{9}{c}{$\mathbf{C}_{\mathrm{NS}}$} \\
\hline $\mathrm{TUH}$ & $\mathrm{DUH}$ & $\mathrm{NIUH}$ & $\mathrm{NIUH}_{\mathrm{GEO}}$ & $\mathrm{CIUH}$ & $\mathrm{CIUH}_{\mathrm{GEO}}$ & $\mathrm{TUH}$ & $\mathrm{DUH}$ & $\mathrm{NIUH}$ & $\mathrm{NIUH}_{\mathrm{GEO}}$ & $\mathrm{CIUH}$ & $\mathrm{CIUH}_{\mathrm{GEO}}$ \\
\hline 0.35 & 0.37 & 0.65 & 0.35 & 0.73 & 0.59 & 27.09 & 24.43 & 18.64 & 32.90 & 18.45 & 14.89 \\
0.46 & 0.38 & 0.95 & 0.71 & 0.98 & 0.38 & 7.27 & 0.90 & 1.07 & 7.92 & 0.73 & 64.26 \\
0.25 & 0.26 & 0.97 & 0.61 & 0.97 & 0.01 & 33.62 & 30.39 & 6.45 & 34.15 & 0.24 & 49.41 \\
-0.37 & -0.47 & 0.98 & 0.77 & 0.99 & 0.29 & 49.67 & 46.45 & 2.43 & 22.53 & 3.06 & 60.33 \\
0.75 & 0.75 & 0.94 & 0.85 & 0.96 & 0.72 & 10.10 & 8.24 & 25.86 & 17.84 & 7.02 & 33.38 \\
0.52 & 0.60 & 0.97 & 0.85 & 0.98 & -1.29 & 31.52 & 25.93 & 0.68 & 29.14 & 4.67 & 77.36 \\
0.80 & 0.78 & 0.94 & 0.77 & 0.99 & 0.87 & 35.88 & 41.83 & 10.96 & 37.10 & 0.24 & 33.29 \\
-0.04 & -0.08 & 0.92 & 0.89 & 0.97 & 0.70 & 55.39 & 52.47 & 23.49 & 10.97 & 14.30 & 18.25 \\
-1.74 & -1.88 & 0.72 & -1.28 & 0.96 & 0.88 & 87.41 & 87.18 & 2.11 & 74.51 & 0.06 & 6.78 \\
-0.62 & -0.63 & 0.84 & -0.47 & 0.97 & 0.92 & 54.36 & 52.65 & 5.00 & 62.19 & 0.86 & 11.77 \\
-0.67 & -1.53 & 0.90 & -0.16 & 0.96 & 0.35 & 72.47 & 93.42 & 10.65 & 48.82 & 10.67 & 56.77 \\
0.89 & 0.85 & 0.97 & 0.95 & 0.97 & 0.75 & 2.33 & 13.49 & 14.77 & 2.63 & 13.29 & 22.00 \\
\hline
\end{tabular}

TUH = Triangular UH; DUH = Dimensionless HU; NIUH = Nash's IUH; NIUH $_{\mathrm{GEO}}=$ Nash's Geomorphological IUH; CIUH = Clark's IUH; $\mathrm{CIUH}_{\mathrm{GEO}}=$ Clark's Geomorphological IUH.

(2010), Bhaskar et al. (1997), Agirre et al. (2005), Nourani et al. (2009) and Sahoo et al. (2006).

It should be pointed out the performance of the $\mathrm{NIUH}_{\mathrm{GEO}}$ for CRW, resulting in estimated hydrographs framed as "Good" or "Very good" (Moriasi et al. 2007) for 8 out of the 12 events. Although $\mathrm{C}_{\mathrm{NS}}$ statistic has indicated this level of performance, peak discharge did not follow this tendency according to $\mathrm{RE}_{\mathrm{Qp}}$ values presented in Table IV. On the contrary, NIUH $_{\text {GEO }}$ did not have satisfactory accuracy in estimating hydrographs for JCW (Table V).

Khaleghi et al. (2011) tested several UH and IUH models for flood estimation in a $68 \mathrm{~km}^{2}$ watershed situated in Iran and verified that the geomorphoclimatic IUH, and the geomorphologic IUH initially developed by Rodriguez-Iturbe and Valdez (1979), had performances superior to TUH, Snyder's UH, DUH and Rosso's IUH. The results found in this study are not in total agreement with Khaleghi et al. (2011), who stated that the geomorphologic IUH $\left(\mathrm{NIUH}_{\mathrm{GEO}}\right)$ can be used as a standard tool for rainfall-runoff transformation in watersheds with scarce data bases.

The results obtained in the present study are in consonance with those reported by Bhaskar et al. (1997), who also found that the NIUH had a performance better than NIUH $_{\mathrm{GEO}}$. These researchers stated that such behavior is expected since the NIUH's parameters are derived from observed data and partially attributed the inferior performance of the $\mathrm{NIUH}_{\mathrm{GEO}}$ to the use of a geomorphological equation for estimation of the NIUH $_{\text {GEO }}$ 's parameters. Bhaskar et al. (1997) highlighted that the equation used is not universal and its transposition for the watershed under analysis is questionable.

Relative to the $\mathrm{NIUH}_{\mathrm{GEO}}$ 's parameters, $n$ was considered constant $(\mathrm{CRW}=3.1$; JCW $=2.9)$ for all the analyzed events. On the other hand, $k$ ranged from 1.25 to $4.93 \mathrm{~h}$ (average value $=3.05 \mathrm{~h}$ ) for CRW, while for JCW, it varied between 0.23 and $0.50 \mathrm{~h}$ (average value $=0.30 \mathrm{~h}$ ). This parameter had a similar behavior to that observed for NIUH. It is 
TABLE V

Nash-Sutcliffe coefficient $\left(C_{\mathrm{NS}}\right)$ and peak stream flow relative error $\left(\mathrm{RE}_{\mathrm{Op}}\right)$ for each rainfall-runoff event monitored at JCW, considering the UH and IUH models analyzed in this study.

\begin{tabular}{|c|c|c|c|c|c|c|c|c|c|c|c|}
\hline \multicolumn{6}{|c|}{$\mathrm{C}_{\mathrm{NS}}$} & \multicolumn{6}{|c|}{$R E_{Q p}(\%)$} \\
\hline TUH & DUH & NIUH & $\mathrm{NIUH}_{\mathrm{GEO}}$ & CIUH & $\mathrm{CIUH}_{\mathrm{GEO}}$ & TUH & DUH & NIUH & $\mathrm{NIUH}_{\mathrm{GEO}}$ & CIUH & $\mathrm{CIUH}_{\mathrm{GEO}}$ \\
\hline 0.68 & 0.72 & 0.83 & -3.20 & 0.98 & 0.34 & 19.92 & 14.95 & 3.10 & 118.22 & 0.27 & 46.53 \\
\hline 0.59 & 0.52 & 0.86 & -2.74 & 0.96 & -0.02 & 7.67 & 17.35 & 21.55 & 121.07 & 5.91 & 68.92 \\
\hline-4.97 & -6.85 & 0.88 & -7.12 & 0.96 & -2.81 & 154.99 & 177.70 & 1.70 & 183.31 & 11.79 & 76.97 \\
\hline-0.87 & -1.02 & 0.82 & -1.63 & 0.99 & 0.53 & 57.60 & 56.61 & 0.85 & 84.22 & 0.67 & 43.09 \\
\hline 0.89 & 0.85 & 0.94 & -1.84 & 0.97 & -0.11 & 14.96 & 24.07 & 13.83 & 116.48 & 8.58 & 78.53 \\
\hline 0.62 & 0.62 & 0.85 & -1.77 & 0.84 & 0.49 & 31.92 & 32.18 & 16.57 & 136.53 & 21.97 & 20.16 \\
\hline 0.06 & 0.03 & 0.84 & -3.47 & 0.94 & 0.26 & 32.54 & 29.00 & 4.22 & 142.63 & 1.32 & 48.58 \\
\hline-0.10 & -0.21 & 0.89 & -2.20 & 0.95 & 0.35 & 32.48 & 26.96 & 11.23 & 108.19 & 5.40 & 53.67 \\
\hline-0.02 & -0.16 & 0.86 & -5.11 & 0.94 & -0.83 & 45.27 & 48.76 & 9.90 & 244.17 & 9.83 & 66.51 \\
\hline 0.71 & 0.63 & 0.78 & -3.97 & 0.80 & -0.41 & 18.99 & 29.61 & 32.01 & 198.42 & 21.80 & 98.85 \\
\hline-4.17 & -7.08 & 0.87 & -15.07 & 0.93 & -3.05 & 169.25 & 206.66 & 2.01 & 385.48 & 2.85 & 133.59 \\
\hline 0.53 & 0.23 & 0.88 & -5.98 & 0.89 & -0.58 & 46.00 & 63.84 & 6.29 & 233.85 & 7.03 & 94.41 \\
\hline-1.22 & -1.85 & 0.78 & -9.46 & 0.80 & -1.59 & 126.49 & 142.60 & 31.27 & 385.38 & 17.93 & 137.98 \\
\hline-0.34 & -0.43 & 0.95 & -4.02 & 0.98 & -0.32 & 42.72 & 38.92 & 3.08 & 147.87 & 5.22 & 78.03 \\
\hline 0.92 & 0.88 & 0.94 & -4.22 & 0.98 & -0.72 & 13.47 & 26.40 & 2.20 & 304.82 & 11.43 & 124.43 \\
\hline 0.44 & 0.36 & 0.20 & -0.46 & 0.85 & 0.77 & 20.43 & 14.83 & 47.93 & 50.45 & 7.23 & 17.44 \\
\hline-0.15 & 0.50 & 0.94 & -7.11 & 0.98 & -1.09 & 84.62 & 52.29 & 5.78 & 249.45 & 3.52 & 111.37 \\
\hline 0.36 & 0.27 & 0.87 & -4.19 & 0.77 & 0.08 & 29.09 & 9.71 & 31.59 & 252.98 & 18.10 & 98.18 \\
\hline-0.51 & -0.63 & 0.93 & -5.32 & 0.91 & -0.31 & 46.78 & 42.45 & 4.46 & 245.97 & 0.11 & 87.86 \\
\hline 0.03 & 0.08 & 0.77 & -4.39 & 0.98 & 0.16 & 43.82 & 41.86 & 21.50 & 168.51 & 5.52 & 39.48 \\
\hline
\end{tabular}

TUH = Triangular UH; DUH = Dimensionless UH; NIUH = Nash's IUH; IIUH $_{\text {GEO }}=$ Nash's Geomorphological IUH; CIUH = Clark's IUH; $\mathrm{CIUH}_{\mathrm{GEO}}=$ Clark's Geomorphological IUH.

worthwhile to highlight the difference in average value of $k$ between NIUH $_{\text {GEO }}$ and NIUH (CRW, $\mathrm{k}=$ $3.25 \mathrm{~h}$; JCW, k=1.72 h), especially for JCW. Such variation in $k$ values for event-by-event analysis has also been reported in literature, such as: i) Adib et al. (2010), using a similar methology, analysed 13 events monitored in a $67.5 \mathrm{~km}^{2}$ watershed in Iran and obtained $n$ equal to 2.83 and $k$ varying from 1.28 and 3.40 h; and ii) Sahoo et al. (2006) verified the applicability of $\mathrm{NIUH}_{\mathrm{GEO}}$ for 15 rainfall-runoff events monitored for an Indian watershed (about $2,800 \mathrm{~km}^{2}$ ) and derived geomorphological variables for modelling with the $\mathrm{NIUH}_{\mathrm{GEO}}$ from topographic maps at the 1:50,000 and 1:250,000 scales. The value of $n$ was 3.74 for the former scale and 3.76 for the latter, whereas, $k$ varied from 1.46 to $2.72 \mathrm{~h}$ for the most detailed scale and between 1.57 and $2.93 \mathrm{~h}$ for the other.

As aforementioned, CIUH resulted in the best accuracies when estimating hydrographs in that all the simulations were categorized as "Very good fit" (Moriasi et al. 2007) for both watersheds under analysis (Tables IV and V). In addition, its performance was substantially superior than NIUH, which was the other adjusted model assessed in this study. Sarangi et al. (2007) verified the performance of the exponentially distributed IUH (EDIUH), CIUH, and spatially distributed 
UH (SDUH) to transform effective rainfall into stream flow in the St. Esprit watershed $\left(21.1 \mathrm{~km}^{2}\right)$, in Canada, and concluded that the EDIUH had the best performance. However, none of the models satisfactorily estimated the DSR hydrograph originated from events with long duration and low intensity, thereby diverging from the findings of this study. The CIUH was capable of appropriately capturing the behavior of hydrographs even for long duration and low intensity rainfall events, as commonly observed in CRW (Table I and Figure 3) due to its climatology.

The results found in this study regarding CIUH agree with those reported by Ghumman et al. (2014), who verified that CIUH had a performance better than NIUH and NIUH $_{\text {GEO }}$ for DSR hydrograph modeling in a watershed in Pakistan. Besides, these authors highlighted the importance of the timearea histogram used by CIUH since it accounts for temporal variability in direct surface runoff in the watershed of interest, while this component is not addressed in the NIUH. Contrarily, Ghumman et al. (2014) found that the NIUH provided the best accuracy for estimation of peak stream flows due to its consideration of a larger number of attenuations when compared to the CIUH.

The CIUH's parameters were quite variable among events analyzed for CRW and JCW; time of concentration $\left(\mathrm{t}_{\mathrm{c}}\right)$ varied from 1.5 to 7.5 $\mathrm{h}$ for CRW and from 1 to $8 \mathrm{~h}$ for JCW, while $R$ had values ranging between 2.37 and $6.82 \mathrm{~h}$ and between 1.00 and $4.38 \mathrm{~h}$ for CRW and JCW, respectively. Such amplitude in $R$ and $t_{c}$ values have been observed in other studies concerning the CIUH (Adib et al. 2010, Kumar et al. 2002, Sahoo et al. 2006, Ahmad et al. 2009). Even though CIUH has demonstrated great potential to estimate hydrographs in CRW and JCW, it has not been widely employed due to the difficulties and limitations when: i) deriving $\mathrm{R}$ for both gauged and ungauged watersheds; and ii) determining the TAH corresponding to the watershed of interest since this task is quite laborious and the existing techniques are not sufficiently applied. Nevertheless, the development and application of the computer tool named as "Watershed Isochrones", which employs several hydrology operations combined with geoprocessing operations, made such task more straightforward, simple and rapid, given the number of TAHs generated for $t_{c}$ adjusted for each event and watershed.

Overall, $\mathrm{CIUH}_{\mathrm{GEO}}$ was not as accuracy as its adjusted version (CIUH) for JCW (Table V). It should be emphasized its performance for CRW (Table IV) in which 7 out of 12 events were satisfactorily estimated; however, peak discharges presented satisfactory estimation for only 5 events according to Van Liew et al. (2007) (see $\mathrm{RE}_{\mathrm{Qp}}$ in Table IV). Because the geomorphologic version of the CIUH used by Kumar et al. (2002) made use of characteristics extracted from the watershed of interest, while CIUH and NIUH were fitted based on the monitored rainfall-runoff events, these authors considered that such geomorphologic model resulted in fair estimated DSR hydrographs.

Adib et al. (2010) assessed the geomorphoclimatic CIUH, NIUH, CIUH and NIUH $_{\text {GEO }}$ to a $66.7 \mathrm{~km}^{2}$ watershed in Iran and pointed out that the former and latter models were capable of adequately estimating DSR hydrographs. These researchers also reported that as the geomorphoclimatic CIUH and $\mathrm{NIUH}_{\mathrm{GEO}}$ do not require rainfall-runoff data sets for calibration, they have been widely employed in hydrology. Comparing the performance of the CIUH, NIUH and two geomorphologic versions of them for hydrograph estimation in an Indian watershed, Sahoo et al. (2006) found that the four models presented fairly accuracy. Nevertheless, according to Sahoo et al. (2006), the fact of not requiring both historical records and calibration makes the geomorphologic versions of CIUH and NIUH advantageous over the conventional CIUH and NIUH. 
The time of concentration $\left(\mathrm{t}_{\mathrm{c}}\right)$ along with the maximum DSR flow length $(23.68 \mathrm{~km}$ for CRW and $10.59 \mathrm{~km}$ for JCW) and drainage area, made it possible to estimate R (Equation 9), resulting in $2.12 \mathrm{~h}$ and $1.28 \mathrm{~h}$ for CRW and JCW, respectively. The values of $\mathrm{t}_{\mathrm{c}}$ and $\mathrm{R}$ used for $\mathrm{CIUH}_{\mathrm{GEO}}$ were quite different from those adjusted by event for CIUH, especially for JCW, thus exerting influence on $\mathrm{CIUH}_{\mathrm{GEO}}$ performance (Table IV). As R and $\mathrm{t}_{\mathrm{c}}$ were not adjusted by event when applying the $\mathrm{CIUH}_{\mathrm{GEO}}$, the procedures used to estimate their values may have exerted considerable impact on $\mathrm{CIUH}_{\mathrm{GEO}}$ modelling. Analogously, evaluating the $\mathrm{CIUH}_{\mathrm{GEO}}$ with 13 rainfall-runoff events, Adib et al. (2010) verified that the values of $t_{c}$ and $R$ for each event were markedly different from those obtained when modelling CIUH adjusted in the environment of the HEC-HMS through monitored data sets. Sahoo et al. (2006) analyzed the influence of topographic maps' scale on determination of the geomorphological variables necessary for $\mathrm{CIUH}_{\mathrm{GEO}}$, considering 15 rainfall-runoff events in an Indian watershed, and found differences in $\mathrm{t}_{\mathrm{c}}$ and $\mathrm{R}$ values.

\section{CONCLUSIONS}

Based on the results presented and discussed in this study, it could be concluded that:

Not only physiographical characteristics (especially those linked to soil), but also the rainfall pattern, exerted influence on the flood modelling;

The CIUH was the model that generated the most accurate surface runoff hydrographs for both watersheds, followed by the NIUH; these models had superiority in relation to the traditionally employed UHs (TUH and DUH) and to $\mathrm{NIUH}_{\text {GEO }}$ and $\mathrm{CIUH}_{\mathrm{GEO}}$;

The geomorphological versions of the CIUH and NIUH presented performances slightly superior when compared to the traditional and simpler models (TUH and DUH), however, they are not recommended to be applied as standard tool for flood modeling in the analyzed watersheds;

Finally, this study indicated that it is recommended to evaluate: i) other approaches existing in literature to derive geomorphological parameters for $\mathrm{NIUH}_{\mathrm{GEO}}$ and $\mathrm{CIUH}_{\mathrm{GEO}}$; ii) the influence of relief information source on determinationofparameters of thegeomorphological IUH models; iii) the application of these models using other ways of spatial discretization of the watersheds for flood modeling, also considering the rainfall spatial distribution.

\section{ACKNOWLEDGMENTS}

The authors wish to thank the Conselho Nacional de Desenvolvimento Científico e Tecnológico (CNPq) for financial support of this research (485279/20134) and scholarships to the first (307523/20144), third (303059/2013-3) and seventh authors, Fundação de Amparo à Pesquisa do Estado do Rio Grande do Sul (FAPERGS) for financial support of this research (2082-2551/13-0) and scholarships to the second and fourth authors, and Coordenação de Aperfeiçoamento de Pessoal de Nível Superior (CAPES) for scholarships to the sixth and eighth authors.

\section{REFERENCES}

ADIB A, SALARIJAZI M, VAGHEFI M, SHOOSHTARI M AND AKHONDALI A. 2010. Comparison between GcIUH-Clark, GIUH-Nash, Clark-IUH, and Nash-IUH models. Turkish J Eng Env Sc 34: 91-104.

AGIRRE U, GOÑI M, LÓPEZ J AND GIMENA F. 2005. Application of a unit hydrograph based on subwatershed division and comparison with Nash's instantaneous unit hydrograph. Catena 64: 321-332.

AHMAD M, GHUMMAN A AND AHMAD S. 2009. Estimation of Clark's Instantaneous Unit Hydrograph parameters and development of direct surface runoff hydrograph. Water Resour Manag 23: 2417-2435.

BESKOW S, CALDEIRA T, MELLO C, FARIA L AND GUEDES H. 2015. Multiparameter probability distributions for heavy rainfall modeling in extreme southern Brazil. J Hydrol Reg Stud 4: 123-133. 
BESKOW S, MELLO C, COELHO G, SILVA A AND VIOLA M. 2009. Estimativa do escoamento superficial em uma bacia hidrográfica com base em modelagem dinâmica e distribuída. Rev Bras Ciênc Solo 33: 169-178.

BESKOW S, NORTON L AND MELLO C. 2013. Hydrological prediction in a tropical watershed dominated by oxisols using a distributed hydrological model. Water Resour Manag 27: 341-363.

BEVEN K. 2011. Rainfall-runoff modelling: the primer, $2^{\text {nd }}$ ed., Chichester: J Wiley \& Sons, 488 p.

BHAGWAT T, SHETTY A AND HEGDE V. 2011. Spatial variation in drainage characteristics and geomorphic instantaneous unit hydrograph (GIUH); implications for watershed management - A case study of the Varada River basin, Northern Karnataka. Catena 87: 52-59.

BHASKAR N, PARIDA B AND NAYAK A. 1997. Flood estimation for ungauged catchments using the GIUH. J Water Res P1 123: 228-238.

BRASIL. 1973. Levantamento de reconhecimento dos solos do Estado do Rio Grande do Sul. Recife: Ministério da Agricultura, Departamento Nacional de Pesquisa Agropecuária, Divisão Pedológica, 431 p.

BRUNDA G AND SHIVAKUMAR N. 2015. Derivation and Analysis of Dimensionless Hydrograph and S Curve for Cumulative Watershed Area. Aquatic Procedia 4: 964-971.

CALDEIRA T, BESKOW S, MELLO C, FARIA L, SOUZA M AND GUEDES H. 2015. Modelagem probabilística de eventos de precipitação extrema no Estado do Rio Grande do Sul. Rev Bras Eng Agríc Amb 19: 197-203.

CEPED - CENTRO UNIVERSITÁRIO DE ESTUDOS E PESQUISAS SOBRE DESASTRES NATURAIS. 2011. Atlas Brasileiro de Desastres Naturais 1991 a 2010, volume Rio Grande do Sul. Universidade Federal de Santa Catarina (UFSC), 93 p.

CHE D, NANGARE M AND MAYS L. 2014. Determination of Clark's Unit Hydrograph parameters for watersheds. J Hydrol Eng 19: 384-387.

CHOI Y, LEE G AND KIM J. 2011. Estimation of the Nash model parameters based on the concept of geomorphologic dispersion. J Hydrol Eng 16: 806-817.

CHOW V, MAIDMENT D AND MAYS L. 1988. Applied Hydrology. McGraw-Hill: New York, 572 p.

CLARK C. 1945. Storage and the Unit Hydrograh. Transactions American Society Civil Engineers 110: 1419-1488.

CLEVELAND T, HE X, ASQUITH W, FANG X AND THOMPSON D. 2006. Instantaneous unit hydrograph evaluation for rainfall-runoff modeling of small watersheds in north and south central Texas. J Irrig Drain E 132: 479485.

EMBRAPA - EMPRESA BRASILEIRA DE PESQUISA AGROPECUÁRIA. 2013. Sistema Brasileiro de Classificação de Solos, $3^{\text {nd }}$ ed., Brasília, 353 p.
ESRI. 2014. ARCGIS DESKTOP 10.1. Redlands, CA: Environmental Systems Research Institute, Inc. (Esri), CD-ROM.

FOLMAR N, MILLER A AND WOODWARD D. 2007. History and development of the NRCS lag time equation. J Am Water Resour AS 43: 829-838.

GHUMMAN A, AHMAD M, HASHMI H AND KAMAL M. 2011. Development of geomorphologic instantaneous unit hydrograph for a large watershed. Environ Monit Assess 184: 3153-3163.

GHUMMAN A, KHAN Q, HASHMI H AND AHMAD M. 2014. Comparison of Clark, Nash Geographical Instantaneous Unit Hydrograph models for semi arid regions. Water Resour 41: 364-371.

HASENACK H AND WEBER E. 2010. Base cartográfica vetorial continua do Rio Grande do Sul - escala 1:50.000. Porto Alegre: UFRGS/Centro de Ecologia. 1 DVD-ROM. (Série Geoprocessamento n. 3).

IUSS WORKING GROUP WRB. 2015. World Reference Base for soil resources 2014. International soil classification system for naming soils and creating legends for soil maps. Update 2015. World Soil Resources Report 106. FAO, Rome: $188 \mathrm{p}$.

JENG R AND COON G. 2003. True form of instantaneous unit hydrograph of linear reservoirs. J Irrig Drain E 129: 11-17.

KHALEGHI M, GHOLAMI V, GHODUSI J AND HOSSEINI H. 2011. Efficiency of the geomorphologic instantaneous unit hydrograph method in flood hydrograph simulation. Catena 87: 163-171.

KUINCHTNER A AND BURIOL G. 2001. Clima do Estado do Rio Grande do Sul segundo a classificação climática de Köppen e Thornthwaite. Disciplinarum Scientia 2: 171182.

KUMAR R, CHATTERJEE C, LOHANI A, KUMAR S AND SINGH R. 2002. Sensitivity analysis of the GIUH based Clark model for a catchment. Water Resour Manag 16: 263-278.

KUMAR R, CHATTERJEE C, SINGH R, LOHANI A AND KUMAR S. 2004. GIUH based Clark and Nash models for runoff estimation for an ungauged basin and their uncertainty analysis. Int J River Basin Manag 2: 281-290.

LÓPEZ J, GIMENA F, GIRÁLDEZ J, AYUSO J AND GOÑI M. 2012. Comparative analysis of a geomorphologybased instantaneous unit hydrograph in small mountainous watersheds. Hydrol Process 26: 2909-2924.

MA F, YE A, GONG W, MAO Y, MIAO C AND DI Z. 2014. An estimate of human and natural contributions to flood changes of the Huai River. Glob Planet Change 119: 39-50.

MCCUEN R AND BONDELID T. 1983. Estimating unit hydrograph peak rate factors. J Irrig and Drain E-ASCE 109: $238-250$. 
MELLO C, NORTON L, PINTO L, BESKOW S AND CURI N. 2016. Agricultural watershed modeling: a review for hydrology and soil erosion processes. Ciênc Agrotec 40: 7-5.

MELLO C, VIOLA M, NORTON L, SILVAAAND WEIMAR F. 2008. Development and application of a simple hydrologic model simulation for a Brazilian headwater basin. Catena 75: 235-247.

MOHAVE COUNTY. 2009. Drainage Design Manual for Mohave County. Star Valley: Arid Hydrology and Hydraulics.

MORIASI D, ARNOLD J, VAN LIEW M, BINGNER R, HARMEL R AND VEITH T. 2007. Model evaluation guidelines for systematic quantification of accuracy in watershed simulations. Transactions of the ASABE 50: $885-900$

NASH J. 1957. The form of the instantaneous unit hydrograph. Int Assoc Sci Hydrol 45: 114-121.

NASH J AND SUTCLIFFE J. 1970. River flow forecasting through conceptual models I: a discussion of principles. J Hydrol 10: 282-298.

NOURANI V, SINGH V AND DELAFROUZ H. 2009. Three geomorphological rainfall-runoff models based on the linear reservoir concept. Catena 76: 206-214.

PERUBAL M AND PRICE RK. 2013. A fully mass conservative variable parameter McCarthy-Muskingum method: Theory and verification. J Hydrol 502: 89-102.

RODRIGUEZ-ITURBE I AND VALDEZ J. 1979. The geomorphologic structure of hydrologic response. Water Resour Res 15: 1409-1420.

RYU J, JANG WS, KIM J, CHOI JD, ENGEL BA, YANG JE AND LIM KJ. 2016. Development of a watershed-scale long-term hydrologic impact assessment model with the asymptotic curve number regression equation. Water 8(4): $1-153$.

SAHOO B, CHATTERJEE C, RAGHUWANSHI N, SINGH R AND KUMAR R. 2006. Flood estimation by GIUHbased Clark and Nash models. J Hydrol Eng 11: 515-525.
SARANGI A, MADRAMOOTOO C, ENRIGHT P AND PRASHER S. 2007. Evaluation of three unit hydrograph models to predict the surface runoff from a Canadian watershed. Water Resour Manag 21: 1127-1143.

SARAVANAN S AND MANJULA R. 2015. Geomorphology based semi-distributed approach for modeling rainfallrunoff modeling using GIS. Aquatic Procedia 4: 908-916.

SCS - SOIL CONSERVATION SERVICE. 1971. National Engineering Handbook. Washington: Soil Conservation Service/USDA.

SEMAD-SECRETARIADEESTADODEMEIOAMBIENTE E DESENVOLVIMENTO SUSTENTÁVEL. 2013. Atlas de vulnerabilidade às inundações - Minas Gerais. Governo do Estado de Minas Gerais, 32 p.

SHERMAN L. 1932. Streamflow from rainfall by the unitgraph method. Eng News-Rec 108: 501-505.

STRECK E, KÄMPF N, DALMOLIN R, KLAMT E, NASCIMENTO P, SCHNEIDER P, GIASSON E AND PINTO L. 2008. Solos do Rio Grande do Sul. UFRGS: EMATER/RS-ASCAR.

SULE B AND ALABI S. 2013. Application of synthetic unit hydrograph methods to construct storm hydrographs. Int J Water Resour Environ Eng 5: 639-647.

VAN LIEW M, VEITH T, BOSCH D AND ARNOLD J. 2007. Suitability of SWAT for the Conservation Effects Assessment Project: Comparison on USDA Agricultural Research Service Watersheds. J Hydrol Eng 12: 173-189.

YADAV B, PERUMAL M AND BARDOSSY A. 2015. Variable parameter McCarthy-Muskingum routing method considering lateral flow. J Hydrol 523: 489-499.

ZAKIZADEH F AND MALEKINEZHAD H. 2015. Comparison of methods for estimation of flood hydrograph characteristics. Russ Meteorol Hydro+ 40: 828-837.

ZELAZINSKI J. 1986. Application of the geomorphological instantaneous unit hydrograph theory to development of forecasting models in Poland. Hydrolog Sci J 31: 263-270. 